University of Nebraska - Lincoln

DigitalCommons@University of Nebraska - Lincoln

To Improve the Academy

Professional and Organizational Development Network in Higher Education

1998

\title{
A Case Study in Getting Faculty to Change
}

Joan K. Middendorf

Follow this and additional works at: https://digitalcommons.unl.edu/podimproveacad

Part of the Higher Education Administration Commons

Middendorf, Joan K., "A Case Study in Getting Faculty to Change" (1998). To Improve the Academy. 409. https://digitalcommons.unl.edu/podimproveacad/409

This Article is brought to you for free and open access by the Professional and Organizational Development Network in Higher Education at DigitalCommons@University of Nebraska - Lincoln. It has been accepted for inclusion in To Improve the Academy by an authorized administrator of DigitalCommons@University of Nebraska - Lincoln. 
Middendorf, J. K. (1998). A case study in getting faculty to change. In M. Kaplan (Ed.), To Improve the Academy, Vol. 17 (pp. 203-224). Stillwater, OK: New Forums Press and the Professional and Organizational Development Network in Higher Education. Key Words: change, change strategies, freshman, organizational development, staff development, thinking skills, teaching methods, workshops.

\section{A Case Study in Getting Faculty to Change}

\section{Joan K. Middendorf}

Indiana University

Academic support professionals have a lot to share with faculty, but it is our special challenge that faculty do not always welcome our help. We can achieve greater success and suffer less frustration by understanding some principles about the process of change. This article offers four principles of implementing change and illustrates their application to a project. If academic support professionals prepare to offset resistance, model a vision of success, involve key people, and match strategies to the stages faculty move through in accepting a change, we can enhance adoption of new approaches.

Academic support professionals ${ }^{1}$ have a lot of expertise to share with
faculty-expertise in university teaching, instructional development,
evaluation, and group process. It is support professionals' special

\footnotetext{
1 I use the term, "academic support professionals," in place of "faculty developers," which can have a negative connotation. It narrows the role of those who support instruction, whether of individual faculty or department or university-wide groups, and it antagonizes faculty because they don't want to be "developed." I include in this group those who work at teaching and learning support centers and administrators, such as department chairs, deans, and other academic officers whose duties include encouraging faculty to improve teaching.
} 
challenge that faculty do not always welcome their help. Guskin (1994) has written about this difficulty.

Restructuring the role of faculty is a monumental undertaking, more difficult and more significant than the administrative restructuring that must precede it. If successful, faculty members will change their present teaching practices and become primarily concerned with enhancing and facilitating student learning. To accomplish this, many faculty will need to acquire additional skills. (p. 25)

Academic support professionals can achieve greater success and suffer less frustration by understanding some basic "truths," or principles, about the process of change and by learning some techniques for facilitating faculty in the acceptance of change. This article offers four change principles and illustrates how to apply them in a typical project.

\section{THE PRINCIPLES}

Four "Truths" About People and Change

RESISTANCE People resist change.

VISION People need to "see" what they're being asked to do.

KEY PEOPLE People are influenced by other people's views of a change.

ACCEPTANCE STAGES People accept a change in relatively predictable stages.

While all of these principles are important, it is the last of thesethat people accept a change in relatively predictable stages - that gives us a powerful guide to planning and implementation. Also, by using an approach based on the acceptance stages, we can account for the first three principles. That is, we can offset resistance, hold out a vision of success, and involve key people. In this way, we increase our effectiveness at getting faculty to buy into and experiment with new approaches.

Before we examine the four principles in more detail, let us look briefly at the faculty development project used here as an examplethe Freshman Learning Project at Indiana University. 


\section{The Freshman Learning Project}

As in many of the nation's universities today, Indiana University faculty are facing a new kind of classroom challenge. The project reported on here-the Freshman Learning Project-is one effort to help faculty better meet the needs of today's students.

The problem. One reason why students and faculty are facing such difficulty in the classroom is a change in sources and availability of information. Students used to need and respect faculty, if for no other reason, because faculty provided unique sources of information. Today, students get an overload of information from television, movies, and the Web. They no longer enter a classroom with the belief that the teacher knows what's best or most current, and they certainly don't believe the teacher knows what's most interesting. In such a classroom environment, what role should a teacher play?

In the past, students received pre-processed information-the results of the faculty member's conceptualization, application, analysis, synthesis, and/or evaluation in the discipline. Now, students are bombarded with information in all content areas (including that of the course) from various media. For example, when students view the movie Amistad, historical information is mixed with fiction. Speeches by screenwriters are intermingled with quotations from actual historical figures-John Quincy Adams interacts with fictional characters (Trudeau, 1998). Because of the multiple, uncontrolled sources of information available to them, today's students need discipline-bydiscipline training in doing critical thinking.

A solution (the change). The Freshman Learning Project takes the position that faculty have a new job and proposes that expertise at that new job will provide at least a partial solution. This new job is to teach students unique thinking skills (e.g., analytic skills, interpretive skills, and problem-solving skills) relevant to the discipline of the course and department.

The Freshman Learning Project aims to help selected faculty (Faculty Fellows) explicate and teach the cognitive competencies of their fields, particularly in large, lower division courses. First faculty will specify the competencies. Then they will teach them to their students through active learning techniques, such as collaborative 
learning groups, writing-to-learn, small-group discussions, role plays, and case studies. These techniques have been shown to increase student preparation time, attentiveness in class, and responsibility for one's own learning (Sorcinelli, 1991).

Project objectives. The Freshman Learning Project, funded by an internal university grant, guided a select group of faculty to (1) specify the cognitive operations students must undertake to do well in their course, (2) better understand freshmen (How do they learn?) and, (3) implement active learning strategies to increase student thinking. Now we can return to the principles of change outlined at the beginning of the article and see how they apply to the specific case of the Freshman Learning Project.

\section{RESISTANCE—and the Freshman Learning Project}

Faculty resist change-for reasons that may be specific to the individual or to the change and for more general reasons (Zaltman \& Duncan, 1977). To understand specific concerns, you need data from those who will be affected by the change. Data-gathering techniques may include observations, informal listening, surveys, and interviews. To understand general concerns, you need only to know what makes all people resist change. These include time, motivation, experience, control, expertise, effort, fear, and rewards.

In the Freshman Learning Project, we looked at faculty's past teaching style, at the change we were asking them to make, and at the kinds of general concerns they were likely to have. Faculty are accustomed to a teaching style that is lecture-based and recall-oriented with faculty controlling the information. We are asking faculty to change to a teaching style that is learner based and cognitive process oriented with the faculty serving as the guide through a mass of unprocessed information from the external world as well as from the course itself. As the means to these ends, we are also asking them to learn and use active learning techniques in the classroom. All of this represents major change for the faculty. To begin the process of understanding, we looked at reasons why our targeted faculty might resist the proposed change. 


\section{Reasons Faculty Might RESIST the Change \\ Proposed by the Freshman Learning Project}

-Time "Sounds to me like this is going to take a lot of time. How much?"

- Motivation "To relate the course to the information students bring from other sources, I'd have to pay attention to what they're interested in, instead of what I'm interested in." "I'm sure my colleagues aren't going to all this trouble and they get by just fine."

- Experience "I never had difficulty with thinking. As a student, I just emulated my professors."

- Control 'I've seen these 'active learning' approaches used in elementary school. The whole classroom is in an uproar. I can just see two hundred college students running around the lecture hall."

- Expertise "I don't know a lot about learning. My background and my interest have always been in my discipline, not education."

- Effort "I can't just change a small part of my teaching. Just tack something on. This approach would affect everything I do-the way I teach, what kind of assignments I make, the kind of tests I give. I'd have to overhaul the whole course."

- Fear "Some students won't like these new ways. (And they'll think I'm flaky.)" "I won't get nearly so much material covered if I try active learning techniques. Students might learn less in the long run."

- Rewards "This department rewards research, not teaching fads."

We accepted these kinds of reasons as not only likely, but natural, and we aimed in our planning to offset and defuse each of them; some of these plans are detailed in the next section. Later, to determine specific concerns, we interviewed each Faculty Fellow.

\section{VISION —and the Freshman Learning Project}

Faculty need to "see" what they're being asked to do and how it's going to help them. As Guskin (1996) writes, "focusing on a vision of 
the future enables people to think holistically about what they are undertaking, to make choices among options along the way, and to defend against the desire to return to the 'here' as the ever-present difficulties emerge in the restructuring process" (p. 35). It's not enough that you see how a certain approach or technology could make a faculty member a better teacher. The faculty member must see. If the image that comes to their minds is that of more work piled on top of what they already have to do, or of a classroom in chaos, no wonder they resist. It is up to you to give them pictures of an improved future that they can internalize-"movies for the mind."

In the Freshman Learning Project, we asked ourselves what vision we wanted to hold up to faculty throughout the project. One way to get a handle on a positive vision is to look at what reasons the faculty might have for accepting a change.

\section{Reasons Why Faculty Might ACCEPT New Approaches}

- Time "Promise me you won't waste my time and I'll give it a try."

- Motivation "I sure would like to look out at a room full of interested students." "It would be nice to have higher student evaluations."

- Experience "I don't have any background with this sort of thing. I'd like to see somebody who's done it before."

- Control "I'm really concerned that the class is going to become bedlam. Are you going to teach me how to handle it?"

- Expertise "It helps to know that we're going to have workshops and support staff to learn how to use these new methods."

- Effort 'I'm used to working hard on my research. I guess it's time I paid more attention to teaching, too.

- Fear "I guess if you folks really know how to do this and you're going to be right there with us through the change, it may not be so bad."

- Rewards "Frankly, the money helps." "The department chair says it is an honor to be chosen for this fellowship." "Do you really think it's possible to have interested students again?" 
These general reasons for acceptance guided our actions in planning and implementing the project. For example, release time and a stipend directly respond to the general concerns related to "time" and "rewards." The provision of support personnel and resources respond to the concerns related to "control" and "fear."

\section{KEY PEOPLE - and the Freshman Learning Project}

Faculty are influenced by other people who can help (or hinder) your efforts. In all but the simplest change, you need to consider the larger social group in which the faculty works-locally, peers, the department, the university; and more widely, the discipline and sometimes even society. Within each of these, there are people-opinion leaders and sponsors-who can offer credibility, resources, and rewards that can make your job more effective and less frustrating.

One group of key people is that of the opinion leaders (Rogers, 1995). What is an opinion leader?

\section{Opinion Leaders...}

... are neither the first nor the last to make a change

...have influence within the faculty

...represent the norms of the faculty group

...are at the hub of the faculty communications network

...observe innovators to see how an idea works or where the dangers lie

...observe latecomers to learn about an idea's limitations

....are relied on by the group for good judgment

...tend to be asked to serve on many committees.

How can you identify opinion leaders? One way is to interview the members of the group. For example, ask faculty members, "When you have a question about new technology, to whom do you turn for ideas?" Such a simple question often leads to a gold mine of information.

Once identified, how should opinion leaders be used? First, they should be used sparingly. Because opinion leaders tend to be sought after for all kinds of committees and projects, they often suffer from 
overload or overexposure. Select opinion leaders with an awareness of their activity load. Then, since they represent the norms of the group, use them as sources of information about the needs of their department regarding current practice. What do the faculty do now in the area of the proposed change? What related needs do they have? What problems? How is the proposed change viewed? If they believe in the change, opinion leaders can become powerful advocates, helping with the planning and communication of the change. Also, through their involvement, you may be able to avoid the "not-invented-here effect": faculty mistrust of developments from outside their own university.

In the Freshman Learning Project, our ultimate goal was to affect whole departments. Therefore, we wanted to start with Faculty Fellows who could serve as opinion leaders within their departments throughout the three years of the project.

In the selection process, we wanted to avoid faculty who have a reputation for trying out every new thing that comes along. In the research on change, such "innovators" are useful as testers or demonstrators of the change, but usually not as opinion leaders. In fact, the "odd-ballness" of those who are the "first by which the new is tried" causes them to lack credibility with their peers (Havelock, 1995). We wanted Faculty Fellows who would have credibility in their departments. With this in mind, we developed a set of criteria. A Faculty Fellow would be...

- tenured

- teaching large introductory classes

- open to new ideas, though not famed for good teaching

- respected by colleagues (i.e., reputation as a researcher)

- not considered a maverick

- congenial with colleagues

To identify appropriate Faculty Fellows, we asked three faculty from each department to nominate colleagues based on our criteria. With a short list of names, our team choose eight (one from each department) who fit the criteria and were not overburdened by other commitments. The result was a list of well-regarded candidates who 
would be willing, for at least a defined period of time, to focus on teaching.

Then, our objective was to get them to accept the role. For this, we needed another type of "Key People" to introduce the project. These people would be the "sponsors" (Dormant, in press) outside the faculty group, who have influence, resources, a commitment to the change, and the respect of the faculty. In addition to the Associate Dean and Assistant Vice Chancellor on the project team, it was easy to get the support of the Dean of the College of Arts and Sciences, since he had declared 1997-98 "The Year of the Student." This project fit his strategic initiative. With several powerful sponsors, we were ready to plan for the stages of acceptance.

\section{STAGES OF ACCEPTANCE-and the Freshman Learning Project}

There are numerous models that describe the stages through which people pass as they accept a change. Although the number of stages differs in the various models, they have many similarities (Zaltman, Florio, \& Sikorski, 1977). The description of the acceptance stages as presented here (see Table 1 in the Appendix) is adapted with permission from the Change MappingSM Participant Guide (Dormant, Middendorf, \& Marker, 1997).

Faculty, as all people do, accept a change in five relatively predictable stages: Awareness, Curiosity, Visualizing, Tryout, and Use. First, people become aware of a proposed change (Awareness). Then, they actively look for information (Curiosity), imagine the change in their lives (Visualizing), get hands-on experience with the change (Tryout), and-if all has gone well enough-integrate the change into their teaching (Use). Of course, at each stage, they may drag their heels or even reject the change altogether.

The remainder of this article details the acceptance stages, suggests matching strategies, and-through the example of our Freshman Learning Project-illustrates how to apply this knowledge to a change project.

Stage 1: Awareness. The first step in getting people to change involves making them aware of the change. In this initial stage, faculty 
are passive - neither seeking nor avoiding information with regard to the change. If the information they receive is more positive than negative, they remain open to receiving additional information about the change. At this first stage of acceptance, a common mistake is to overwhelm faculty with intensive information campaigns or training programs. However, when people barely know anything about the topic, they don't want to be loaded down with information. Instead, for Stage 1: Awareness, be short and sweet! Be positive. Get their attention with a few bits of information that appeal to their needs. Our job is to Advertise!

For Stage 1: AWARENESS

- poster campaign

\section{ADVERTISEMENT examples}

- announcement on building kiosk

- upbeat, brief newsletter article by credible source

- e-mail teaser

- brief memo from respected source

In the Freshman Learning Project, we decided on a brief letter from the Dean of the College to the individual faculty members announcing the project and emphasizing its importance. The letter gave few details, but it did attempt to appeal to faculty needs and values (as indicated by italics below).

We kept the letter short, with only a few details-"better achieve their pedagogical goals." It stressed the positive-"someone whose commitment to teaching...makes you an ideal participant." We appealed to their needs with a $\$ 5,000$ summer grant and intensive support.

This "short and sweet" strategy worked. All eight faculty members accepted our offer. Moreover, when we met with one of their department chairs (who had received a similar letter inviting departments to participate), he told us, "I don't know much about the project, but what I do know sounds good. You will receive full support from this department, but I would like to know more about what is involved." 


\section{Dear Professor XXXX:}

I write to invite you to become a Fellow of the I.U. Freshman Learning Project, a new program designed to help faculty better achieve their pedagogical goals in large freshman courses. You have been identified as someone whose commitment to teaching and influence within the Bloomington academic community makes you an ideal participant in this effort.

Freshman Learning Project Faculty Fellows will work closely with the members of their departments to devise new approaches to large introductory courses in their disciplines and will participate with fellows from seven other departments in a two-week workshop on teaching first-year students to be held on the Bloomington campus early in the summer of 1998.

With the assistance of funds from the College of Arts and Sciences, the Dean of Faculties Office, and the Strategic Directions Charter, the Freshman Learning Project will provide the Fellows with a $\$ 5,000$ summer grant and with intensive staff support and materials from the Teaching Resources Center, the Campus Writing Program, and the Teaching and Learning Technology Lab.

Professor XXXX, the director of the Freshman Learning Project, will be contacting you to discuss your participation. If you decide that you would like to become a Fellow, and your chair is prepared to commit your department to this effort, we will formally announce your participation in the program to the campus in early November.

Sincerely,

\section{$\mathrm{XXX} \mathrm{XXXX}$}

Dean of the College of Arts and Sciences

Stage 2: Curiosity. Once aware of the change, people become curious. They begin to ask questions and look for information. Also, they become concerned about how the new approach will affect them personally. "What demands are going to be made on me?" "Will my role change?" "Will I lose my right to decide what I do?" "Will the rewards change?" If people don't get good information about the change, they may take much longer to accept or they may reject the change. Our job is to Inform. 
For Stage 2: CURIOSITY

- 20 questions-most-often-asked flyer

- pamphlet featuring positive outcomes

- overview by credible, informed, articulate presenter

- informal discussion with respected, informed colleague

- bite-sized communiqués on major features

- Q \& A sessions scheduled in regular departmental meetings

In the Freshman Learning Project, once Faculty Fellows had received the Dean's invitational letter, the Project Co-Director (who was himself a faculty member) phoned each individual. Even as he made appointments to meet with them, their concerns began to emerge. Some had specific, individual questions. Several had strong reservations about the projected schedule. Clearly, time was a major concern.

As a result of this preliminary data-gathering, we revised the proposed schedule. Originally we wanted Fellows to commit a block of six to eight weeks of their summer solely to this project. In response to Fellow needs, we redesigned the program so that the only block of time solely committed to this project would be a two-week summer workshop. This workshop would become the centerpiece of a year of more individualized work with the Fellows and their departments. Clearly, from the Faculty Fellows' perspective, this schedule was superior to the original plan. The revision also sent the message that we were responsive to the faculty needs.

Prior to the workshop, but at their own pace and with support staff help, each would analyze one course, identifying the cognitive tasks of the students for the course. After the workshop, on their own timeline and still with support staff help, they would design learning activities for each class session. Thus, the work was spread out over a longer period so that faculty members would not have to drop everything else.

Our team also responded to specific, individual concerns. For example, the anthropology faculty member worked overseas during part of the summer designing her learning activities. Another Fellow was concerned about having to present the change to her department. 
(This was a second-year task for the Faculty Fellows.) We reassured her that we would help her make a plan for this and that it would not be her responsibility alone. Another Fellow was enthusiastic about the project, but had a conflict. He would be teaching a course part of every day during the scheduled two-week summer workshop. However, he had taught the course before, and he was willing to devote several extra hours daily to study and preparation regarding workshop content. We decided it would be a mistake to lose him. Our goal was to take faculty concerns into account while maintaining the integrity of the project.

Stage 3: Visualize. When personal concerns are adequately met during Stage 2, faculty move from a focus on themselves to more task-oriented concerns. Potential users of a change begin to try out the change mentally in Stage 3: Visualize and to think about how it would work in their situation. Our job then is to Demonstrate - to provide specific examples of the change in action, to facilitate the faculty's "movie in their mind" of the new teaching methods. In the absence of information upon which to create a good movie, faculty may "horribilize," or imagine a worst case scenario. At this time, our job is to provide the raw material for positive visualization.

For Stage 3: VISUALIZING

- visits to model classrooms

DEMONSTRATION examples

- videotaped examples

- success stories in newsletter

- formal presentations by faculty or experts

- informal meetings with peers

- teleconferences

We had three objectives at initial meetings of Faculty Fellows. First, we wanted the Faculty Fellows to become a functional team. They would be collaborating over the next year through monthly meetings to exchange ideas, problems, and experiences regarding their efforts to change the way they teach. We scheduled several teambuilding activities for this first meeting. In one, they paired up to describe their worst learning experience as undergraduates. These 
activities also gave the Fellows an experience as "students" in an active learning situation.

Second, we wanted them to get a vision of success. To achieve this objective, we invited respected faculty who had successfully changed their own teaching approaches. One, for example, talked briefly about how he had analyzed the thinking skills relevant to his discipline; another described how he had begun to use active learning techniques in the classroom.

Third, we devised a system for the Fellows to observe the large, freshman classes of other campus faculty. We proposed these observations as opportunities to better understand what it's like to learn in a large lecture course. Subsequent discussions with each other and our team helped faculty to better understand the student's perspective.

Stage 4: Instruct. If faculty can see how they might benefit from a change ("good movie in their minds"), they may move on to the Tryout Stage, where our job now is to Instruct faculty and to provide opportunities for practice and feedback. In Stage 4, they are ready to learn about the change and get hands-on experience, asking, "How can I do this myself?"

For Stage 4: TRYOUT

- workshop on new approach

- reprints of relevant articles

- a how-to manual or video

- computer modules

- mentors with experience

- "master" class

- microteaching

In the Freshman Learning Project, Faculty Fellows were ready to learn about active learning techniques and implement new approaches in their classrooms. Some faculty already had ideas and were ready to try them out, while others were still gathering information. Because some faculty might prefer to self-instruct through reading, we gave 
each faculty member Active Learning: 101 Techniques to Teach Any Subject (Silberman, 1996).

Each Faculty Fellow was paired with one instructional support staff member to collaborate on designing activities and finding articles related to teaching in that Fellow's discipline. It was during this period that the Fellows participated in the two-week workshop focused on understanding freshmen learners. We invited experts on student life to talk to the group. Staff from Student Residence Halls as well as faculty who have researched student development provided insights about students. We brought in Jean MacGregor, a nationally known expert on learning communities and collaborative learning. The faculty learned more about structured group activities by hearing what other faculty were doing and trying some themselves. Some of the faculty were in Stage 4 for a long period, a semester or more, learning about and trying active learning techniques.

Stage 5: Use. If faculty feel reasonably confident about their competency with a new approach or technology, they may begin to integrate it into their day-in, day-out work. When faculty are in Stage 5: Use, our strategy is to Support. At this stage, faculty are trying to apply what they learned in Stage 4. This is a difficult stage for them. Their mastery is imperfect, and things that sounded good in planning discussions may not work so well in the classroom. Even at this stage, they may still reject the change unless faculty get two kinds of support: technical support and the support of rewards.

Technical support must be available when faculty need it. Otherwise they may be overwhelmed by frustration and feelings of failure, and they may fall back to their old ways of teaching.

For Stage 5: USE

- one-on-one consultant

- expert available by e-mail

- telephone consulting service

- peer user network

- troubleshooting handbook provided

- regularly scheduled brown bag lunches 
In the Freshman Learning Project, academic support staff who were experts on the analysis of discipline-specific thinking skills and active learning techniques were available in a timely fashion to answer faculty members' questions, observe their efforts, and suggest modifications. Sometimes a Fellow needed individualized support. For example, one faculty member realized she didn't know how to grade students on in-class discussions or in-class writings. How could she fit this into her grading system? The academic support staff gave her several models to follow. Other faculty members tended not to ask for help. Therefore, it was important for their assigned support staff member to check in frequently: "How's it going?" "Do you need some help?" "Here's an article I thought you'd find of interest."

Rewards are often neglected in change projects, but, like all people, faculty also need the support of rewards if they are to continue to integrate a change (and to be willing to try other, future changes). The university may say it is supportive of change, but does it reward the risk taking inherent in making a change? Luckily, rewards come in different forms, and different things are rewarding to different people. Professionals, such as faculty, who are self-motivated and committed to their work, often prefer rewards other than money, such as recognition by the Dean, professional associations, or even local newspapers. (Notice the importance once again of Key People.)

The Freshman Learning Project involved several kinds of rewards. All Faculty Fellows were paid five thousand dollars for a full year's participation. But, since money is not always the top motivator

For Stage 5: USE

- newsletter recognition

\section{REWARD examples}

- acknowledgement at departmental meeting

- salary merit increases

- travel funds for conference attendance

- course-load reduction

- special desirable assignment

- summer funding

- research assistant(s)

- meals/social gathering 
for faculty, we planned other rewards, mostly involving publicity for their efforts. Some faculty appeared on panels to let the other faculty know about their efforts. The project was featured prominently in the annual reports of department chairs for the Dean and the Board of Trustees. We worked with the campus publicity bureau to publish articles in the campus and town newspapers. An article about the project appeared on page one of the town newspaper ("Faculty Seminar Produces Ideas Focused on Learning," Wright, 1998). Another reward for this particular group, which had "bonded"so well with each other, was continued social gatherings, parties, and meals together away from campus that they arranged for themselves.

The two forms of support for Stage 5, technical support and rewards, encouraged faculty to go on when they encountered difficulties with new techniques in the classroom. Without this support, the faculty may have become frustrated and abandoned new approaches.

\section{Summary}

We self-consciously planned with the four principles for implementing change described in this article-offset resistance, model a vision of success, involve key people, and match strategies to the stages faculty move through in accepting a change. Thus, we were able to get the results we intended, a cadre of faculty strongly committed to changing teaching and advocates for similar changes among their colleagues. We learned again from our experience the usefulness of this model, but also the challenges of being a change agent.

Any support professional who is successful at getting faculty to accept significant change is likely to plan obsessively, experience considerable frustration, and-when things go well-have a sense of being invisible. As for the latter, it seems that the more effective one is as a change agent, the more likely that others will take the credit. In fact, one measure of an expert support professional is that the targeted faculty and key people feel the satisfaction of having done the job themselves.

So what are some skills a good academic support professional needs to be effective and to survive? In addition to a knowledge of the basic principles and strategies of change, the effective change agent 
needs an understanding of the university system, skill at communicating and team building, a high tolerance for ambiguity, flexibility in the face of the unexpected, someone from outside the system to talk to about the project and the frustrations involved, and a basic respect for others and for oneself. The academic support professional has an incredibly challenging and worthy job-to help faculty become better at teaching today's university students.

\section{References}

Dormant, D. (in press). Implementing human performance in organizations. In H. D. Stolovitch \& E. J. Keeps (Eds.), Handbook of human performance technology (2nd ed.). San Francisco: Jossey-Bass.

Dormant, D., Middendorf, J. K., \& Marker, A. W. (1997). Change mapping ${ }^{S M}$ participant guide. Bloomington, IN: Dormant \& Associates.

Gardiner, L. F. (1997). Producing dramatic increases in student learning. National Teaching and Learning Forum, 6(2), 8-10.

Guskin, A. E. (1996). Facing the future. Change, 28(4), 27-37.

Guskin, A. E. (1994). Restructuring the role of the faculty. Change, 26(5), 16-25.

Havelock, R. G. (with Zlotolow, S.). (1995). The change agent's guide (2nd ed.). Englewood Cliffs, NJ: Educational Technology Publications.

Rogers, E. M. (1995). Diffusion of innovations (4th ed.). New York: The Free Press.

Salomon G. (1997). What does the design of effective cscl require and how do we study its effects? [Online]. Available: http://wwwcsc195.indiana.edu/csc195/outlook/62_Salomon.html

Schein, E. H. (1985). Organizational culture and leadership: A dynamic view. San Francisco: Jossey-Bass.

Silberman, M. (1996). Active learning: 101 strategies to teach any subject. Boston, MA: Allyn and Bacon.

Sorcinelli, M. D. (1991). Research finding on the seven principles. In A. Chickering \& Z. Gamson (Eds.)., Applying the seven principles for good practice in undergraduate education. New Directions for Teaching and Learning, No. 47 (pp. 13-25). San Francisco: Jossey-Bass.

Trudeau, G. (1997, December). Amistad is important. Time, 150(27), 170.

Wright, M. (1998, May). Faculty seminar produces ideas focused on learning. HeraldTimes, A1.

Zaltman, G., Florio, D., \& Sikorski, L. (1977). Dynamic educational change. New York: Free Press. 


\author{
Contact: \\ Joan K. Middendorf \\ Director, Teaching Resources Center \\ Ballantine Hall, Room 132 \\ Indiana University \\ Bloomington, IN 47405-6601 \\ 812-855-2635 \\ 812-855-5656 FAX \\ middendo@indiana.edu
}

Joan Middendorf has been the Director of the Teaching Resources Center of the College of Arts and Sciences at Indiana University for a decade. She collaborates with faculty instructors and administrators to diffuse pedagogical innovations and publishes about college teaching and change in higher education. In addition, she co-directs the Freshman Learning Project. As the designer of The Change Mapping SM Workshop, Joan has presented on leading change at more than 20 corporations. She studies T'ai Chi for relaxation and as an exercise in learning. 


\section{Appendix}

Questions to Guide Discussions of the Four Principles (Be aware that you and your team may spend several hours on each of these questions.)

\section{Resistance}

1. What reasons might your faculty give for resisting the change?

2. What reasons might your faculty give for accepting the change?

\section{Vision}

1. What was the culture of your university in the past?

2. What is it now?

3. What is the vision you are aiming for?

\section{Key People}

1. What are the characteristics you want in your opinion leaders?

2. Who are your potential opinion leaders?

3. What do you want them to do?

\section{Stages of Acceptance and Strategies}

Stage 1: Awareness-ADVERTISE

How will you attract positive attention for your project?

Who might best send this message?

Stage 2: Curiosity-INFORM

How will you provide relevant, timely information to address faculty personal concerns about the change?

\section{Stage 3: Envision-DEMONSTRATE}

In order to facilitate positive "movies" in the minds of faculty, how will you give them a way to...

a. see the change in action?

b. read about (or watch a video of) the change in action?

c. hear a presentation about the change?

d. network with satisfied peers? 


\section{Stage 4: Tryout-INSTRUCT}

How will you help faculty acquire the skills and knowledge they need to use the change effectively?

Stage 5: Use-SUPPORT-Plan For Two Kinds Of Support How will technical support be provided for your faculty after training? Is approval needed? From whom?

What would be rewarding to your faculty? Who will provide the rewards? When? 


\begin{tabular}{|c|c|}
\hline \multicolumn{2}{|c|}{$\begin{array}{l}\text { TABLE } 1 \\
\text { Stages of Acceptance and Strategies for the Change Agent }\end{array}$} \\
\hline Stages & Strategies \\
\hline $\begin{array}{l}\text { Stage 1. - AWARENESS } \\
\text { In this stage, faculty } \\
\text { are passive regarding the change } \\
\text { have little/no info. about the change } \\
\text { have little/no opinion about the change }\end{array}$ & $\begin{array}{l}\longrightarrow \text { USE "Catch their interest" } \\
\text { Activities include those that } \\
\text { get attention } \\
\text { are brief and positive } \\
\text { appeal to faculty's perceived needs }\end{array}$ \\
\hline $\begin{array}{l}\text { Stage } 2 \text { - CURIOSITY } \\
\text { In this stage, faculty } \\
\text { are more active regarding the change } \\
\text { have self-focused concerns and } \\
\text { opinions } \\
\text { ask questions about the impact on } \\
\text { them }\end{array}$ & $\begin{array}{l}\longrightarrow \text { Inform "Anticipate their concerns!" } \\
\text { Activities include those that } \\
\text { lessen faculty concerns } \\
\text { answer user questions } \\
\text { provide relevant information }\end{array}$ \\
\hline $\begin{array}{l}\text { Stage } 3 \text { - ENVISION } \\
\text { In this stage, faculty } \\
\text { imagine how the change fits with the } \\
\text { job } \\
\text { have job-focused concerns } \\
\text { ask question about task and job impact }\end{array}$ & $\begin{array}{l}\longrightarrow \text { DEMONSTRATE "Show them it works!" } \\
\text { Activities include those that } \\
\text { show the change in action } \\
\text { provide examples of success } \\
\text { network faculty with satisfied peers }\end{array}$ \\
\hline $\begin{array}{l}\text { Stage } 4 \text { - TRYOUT } \\
\text { In this stage, faculty } \\
\text { have opinions about the change and } \\
\text { its use } \\
\text { are interested in learning how to use } \\
\text { ask questions about department and } \\
\text { organization impact }\end{array}$ & $\begin{array}{l}\rightarrow \text { INSTRUCT Teach them how to use it" } \\
\text { Activities include those that } \\
\text { provide necessary information } \\
\text { provide knowledge/skills acquisition } \\
\text { result in desired performance }\end{array}$ \\
\hline $\begin{array}{l}\text { Stage } 5 \text { - USE } \\
\text { In this stage, faculty } \\
\text { use the change on the job } \\
\text { ask detailed questions and need help } \\
\text { make suggestions for improvements }\end{array}$ & $\begin{array}{l}\longrightarrow \text { SUPPORT "Stay with them!" } \\
\text { Activities include those that } \\
\text { maintain faculty contact } \\
\text { provide technical help } \\
\text { reward and reinforce }\end{array}$ \\
\hline $\begin{array}{l}\text { Adapted with permission from the Char } \\
\text { Associates, 1997) }\end{array}$ & Mapping ${ }^{\text {SM }}$ Participant Guide (Dorm \\
\hline
\end{tabular}

